\title{
As Transmissões Midiáticas das Sessóes de Julgamento do Supremo Tribunal Federal
}

\author{
Thiago Coelho Sacchetto*
}

\begin{abstract}
1 Introdução. 2 A TV justiça e as suas funções. 3 O regramento normativo e o incipiente debate sobre a transmissão das sessões de julgamento do supremo tribunal. 4 A necessidade de avaliar a prática em correspondência com a natureza jurídica das respectivas competências jurisdicionais. 5 Conclusão. Referências.
\end{abstract}

\begin{abstract}
RESUMO
Examina-se neste trabalho a história, os objetivos, o regramento normativo e o debate existente na doutrina jurídica brasileira sobre a inovadora prática adotada pelo Supremo Tribunal Federal de permitir a transmissão ao vivo e integral de parcela das suas sessões de julgamento pelos meios de comunicação em massa. A fim de aclarar as diversas controvérsias relacionadas ao instituto garantidor do direito à informação - de maneira dogmática - recomenda-se a avaliação da prática, considerando-se, especificadamente, as singularidades e a natureza jurídica das competências jurisdicionais atribuídas pela Constituição da República ao Supremo Tribunal Federal.
\end{abstract}

Palavras-chave: Supremo Tribunal Federal. TV Justiça. Jurisdição Constitucional. Direito e Sociedade. Direito à Informação.

\section{INTRODUÇÃO}

Diante de um cenário de exposição midiática e institucional vivenciado pelo Supremo Tribunal Federal, sem precedentes na história nacional, a questão da transmissão ao vivo de parcela de suas sessões de julgamentos tem divido opiniões de especialistas quanto aos efeitos advindos da prática pioneiramente adotada pela Corte.

Há estudiosos que, para evitar que o Tribunal se torne refém de pressões externas, defendem que os princípios da publicização e da transparência não devem ser interpretados como mandamentos pela irrestrita exposição dos votos e das discussões realizadas pelos Ministros da Corte. Outros, por sua vez, dando importância basilar a concepções democráticas que idealizam uma permeabilização crescente da participação do povo nas questões da Justiça, entendem que os deveres de publicidade e transparência nas atividades jurisdicionais são imposições teleológicas inseridas na Constituição Federal de 1988.

* Professor da Pontifícia Universidade Católica de Minas Gerais. Doutorando em Direito Político pela Universidade Federal de Minas Gerais. Mestre em Ciências Jurídico-Políticas pela Faculdade de Direito da Universidade de Lisboa. Pós-Graduado em Advocacia Pública pelo Instituto para o Desenvolvimento Democrático. E-mail: <tcsacchetto@gmail.com>. 
Efetivamente, tal como tem sido feito, o juízo de mérito sobre a pertinência da prática deve depender de valorações precipuamente subjetivas e opinativas, ou, de maneira mais científica, seria possível avaliá-la por intermédio de critérios, até certo ponto, mais objetivos e dogmáticos? Com o objetivo de responder ao problema, examinam-se no presente artigo as principais argumentações utilizadas pelos defensores e detratores da práxis, correlacionando-as à necessidade de que o juízo dogmático sobre a temática seja feito com sensibilidade para a natureza jurídica das competências exercidas pelo Tribunal.

Nesse escopo, com metodologia jurídico-sociológica (GUSTIN; DIAS, 2015, p. 22), examinam-se os aspectos históricos e culturais que motivaram a criação da TV Justiça e fomentaram a prática de transmitirem-se ao vivo e integralmente algumas das sessões de julgamento do Supremo Tribunal Federal, ao passo que, concorrentemente, pela vertente metodológica jurídico-dogmática (GUSTIN; DIAS, 2015, p. 21), analisam-se os dispositivos normativos aplicáveis a esse uso constitucional.

Valendo-se do tipo de investigação jurídico-interpretativo (GUSTIN; DIAS, 2015, p. 28-29), analiticamente, decompõem-se as diversas competências jurisdicionais do Supremo Tribunal Federal em três grandes grupos (competências penais; competências variadas e competências em fiscalização constitucional), por meio das quais se constroem assertivas jurídico-propositivas (GUSTIN; DIAS, 2015, p. 29) acerca do melhor regime de publicidade aplicável para as respectivas competências.

Sem a pretensão de alcançar um resultado conclusivo acerca do regime de publicidade adequado para as competências jurisdicionais exercidas pelo Supremo Tribunal Federal em matéria penal ou de natureza variada, a pesquisa aponta que, no que concerne ao exercício da fiscalização de constitucionalidade de atos normativos, a obrigação estatal de dar ampla transparência aos atos jurisdicionais praticados pela Corte Suprema trata-se efetivamente de um dever fundamental do Estado Democrático de Direito.

\section{A TV JUSTIÇA E AS SUAS FUNÇÕES}

O Supremo Tribunal Federal foi a primeira Corte constitucional do mundo a transmitir integralmente e regularmente os seus julgamentos por intermédio de um canal audiovisual, como a TV Justiça, que iniciou as transmissões ao vivo das suas sessões plenárias em 14 de agosto de 2002 (BRASIL, 2017).

A implementação das transmissões ao vivo e integrais das sessões do Supremo Tribunal Federal tornou-se possível com a aprovação do Projeto de Lei n. ${ }^{0}$ 6.059/02, responsável por instituir um canal televisivo reservado à Corte para a divulgação dos atos do Poder Judiciário e dos serviços essenciais à Justiça, que foi coordenado desde o seu nascimento pela Assessoria de Imprensa do Supremo Tribunal Federal. ${ }^{1}$

A Exposição de Motivos que fundamentou a norma de criação do canal reservado ao Supremo Tribunal Federal baseou-se na necessidade de oferecer aos cidadãos a oportuni- 
dade de conhecer de forma mais ampla o funcionamento do Poder Judiciário e de permitir a democratização do acesso à informação aos atos praticados por esse Poder. ${ }^{2}$

Como atestam alguns estudos, a criação e o desenvolvimento da TV Justiça representou a materialização de diversos esforços envidados por autoridades e assessorias de comunicação com o intuito de tornar compreensíveis os atos e fatos da atividade judicial (SILVA, 2005, p. 47), a exemplo do que os canais da televisão legislativa já faziam. ${ }^{3}$

A fim de definir as feições que a emissora teria, vários debates foram realizados por meio do Fórum Nacional de Comunicação e Justiça, e com o envolvimento de autoridades e assessores de comunicação social pertencentes ao Judiciário e às diversas funções essenciais, almejou-se a construção de uma programação plural para o canal novel. ${ }^{4}$

Logo que a TV Justiça entrou no ar e iniciou as suas atividades ganharam destaque na mídia as transmissões regulares e ao vivo dos julgamentos das sessões plenárias do Supremo Tribunal Federal, tanto pelos seus aspectos inovadores como pelo interesse que despertaram no público, eis que permitiram aos espectadores entrar em contato direto com os debates promovidos pelo órgão de cúpula do Judiciário nacional, sem que, para isso, precisassem estar fisicamente presentes em Brasília.

Iniciadas em agosto de 2002, como parte da programação criada para a recém-inaugurada TV Justiça, as transmissões das sessões plenárias de julgamento do Supremo Tribunal Federal eram veiculadas no programa semanal "Justiça em Ação" e, prefacialmente, não eram integralmente reproduzidas pelos meios de comunicação.

No entanto, com o amadurecimento da experiência e com a ampla demanda pelo acesso à informação pública advinda dos telespectadores e da imprensa, três meses depois de iniciar as transmissões das sessões plenárias, de modo parcial e editado, a TV Justiça começou a veiculá-las, integralmente e ininterruptamente (SILVA, 2005, p. 51-52).

É importante ressaltar que a escolha inicialmente feita pelos gestores públicos de concentrar as atividades de comunicação da Suprema Corte brasileira no aparelho de televisão, inequivocadamente, refletiu uma bem sucedida análise da predominância desse instrumento como principal via de acesso da população brasileira às informações, como é possível se constatar com o exame de dados colhidos à época. ${ }^{5}$

Posteriormente, com o propósito de conferir mais transparência ao órgão e aproximar a Corte constitucional da sociedade, a assessoria de comunicação do Supremo Tribunal Federal passou a transmitir as sessões de julgamento do Tribunal, também, por outros canais midiáticos, como a rádio, a Internet, além de incluir as suas pautas em vários meios de divulgação, como Twitter, Youtube, boletins jornalísticos, entre outros. ${ }^{6}$

Responsável não apenas pela transmissão das sessões plenárias do Supremo Tribunal Federal, a TV Justiça faz parte de um plano institucional do Poder Judiciário brasileiro cuja finalidade precípua é aproximar esse Poder dos cidadãos e, para tanto, realiza a divulgação de suas ações institucionais e de outros órgãos judiciais, aborda temas jurídicos complexos em linguagem acessível ao público, promove aulas, realiza debates e explicita 
em caráter didático as diversas questões jurídicas tratadas nos processos submetidos à Suprema Corte.

Os objetivos de aproximar assuntos judiciais do cidadão e de permitir acesso fidedigno às informações judiciárias, de forma a preencher os espaços e as imprecisões deixados pelas emissoras comerciais, são desígnios manifestos desse meio de comunicação que se apresenta como uma mídia que "tem como foco preencher lacunas deixadas por emissoras comerciais em relação a notícias sobre questões judiciárias.” (TV JUSTIÇA, 2017a, online). Daí ser possível afirmar que, desde a sua gênese, esse canal midiático tem a preocupação cívica e institucional de ampliar os conhecimentos dos jurisdicionados sobre importantes questões jurídicas debatidas em âmbito nacional.

Como é usual ocorrer, ao versar sobre processos jurídicos nos seus noticiários, a imprensa comercial costuma dar um tratamento exageradamente condensado, incapaz de esclarecer importantes aspectos dos eventos jurídicos abordados, muitas vezes, em razão do formato reduzido de tempo/espaço que os seus editoriais possuem. ${ }^{7}$ Como consequência, geralmente as coberturas sumariamente feitas pelos veículos comerciais, sobre questões jurídicas, acabam aguçando a sensação de desconhecimento do cidadão em relação ao Judiciário.

Ao prestar uma informação clara, completa e contextualizada, os idealizadores da TV Justiça acreditam que a emissora é capaz de romper com o sentimento de desconfiança e impotência que o noticiário tradicional costuma impingir nos cidadãos, já que visa a instruí-los sobre o funcionamento da ordem jurídica e, nesse desiderato, fomenta o senso crítico e a capacidade de compreenderem os problemas jurídicos de forma abrangente e não simplificada.

Busca-se, com essa mídia, atenuar os efeitos perniciosos que a cobertura jornalística comercial pode provocar quando, manifestamente, destaca o que é contraditório, estranho e negativo nas decisões judiciais, além de também permitir que os telespectadores possam, com maior capacidade, examinar os problemas jurídicos por uma perspectiva comunicativa técnica e, ao mesmo tempo, simplificada. ${ }^{8}$

Destaca-se na programação da TV Justiça, que fica no ar 24 horas diariamente, a existência de mais de 50 (cinquenta) programas televisivos regulares, que abordam um variado rol de assuntos jurídicos como direitos fundamentais das pessoas, Direito Eleitoral, Poder Judiciário, Direito Internacional, Advocacia, Direito Comparado, Defensoria Pública, Direito do Trabalho, Meio ambiente, Legislações, Ministério Público, Direitos Humanos, entre outros temas que são tratados por intermédio de diferentes perspectivas metodológicas, alternando entre programas de entrevistas ou de debates, programas de cunho informativo ou acadêmico, com foco didático ou de esclarecimento sobre o funcionamento de instituições, de natureza jornalística ou mesmo dirigidos a fornecer lições históricas sobre o Direito ou sobre as notáveis personalidades jurídicas. ${ }^{9}$

Conforme veiculado em revistas especializadas alguns meses antes de a emissora ser inaugurada, a programação da TV Justiça, ao contrário do que alguns imaginavam, foi con- 
cebida não para privilegiar os profissionais da área jurídica, mas sim para atingir o público não especializado em Direito ao traduzir o funcionamento do Poder Judiciário e ampliar a sua transparência (ALVES; FIUZA, 2002, p. 42).

Dentro da sua programação, sobressaem com proeminência do interesse do público e da doutrina jurídica as transmissões ao vivo e integrais das sessões plenárias do Supremo Tribunal Federal, tanto pela repercussão social que provocam como pela inovadora situação jurídica que criaram, ao exporem a um critério máximo de publicidade e transparência os julgamentos e os debates promovidos pelos membros do órgão de cúpula do Poder Judiciário.

Com efeito, a iniciativa do Supremo Tribunal Federal de instituir e permitir a transmissão integral e ao vivo das suas sessões de julgamento, de forma regular, pode ser qualificada como uma atitude representativa do compromisso assumido pelo órgão de, efetivamente, dar transparência aos seus atos jurisdicionais, não só em uma perspectiva meramente formal, mas também substancial, ainda que a prática atualmente se restrinja às sessões de julgamento do órgão Plenário da Corte e não se estenda às sessões de julgamento de suas Turmas.

As transmissões ao vivo e integrais das sessões plenárias do Supremo Tribunal Federal, nos períodos laborais da Corte, são veiculadas semanalmente pela TV Justiça nas quartas e nas quintas-feiras, sem qualquer interrupção, e acompanham na íntegra todos os atos e eventos que ocorrem durante essas sessões a fim de reproduzi-los de maneira realística, completa e fidedigna.

Elogiosamente, com o intuito de contextualizar o telespectador a respeito dos julgamentos que serão efetuados pelo Tribunal, antes das transmissões, a TV Justiça detalha na sua programação os processos que estão previstos para a pauta do dia e, durante as sessões, faz eventuais esclarecimentos sobre seus aspectos fáticos e jurídicos à medida que são julgados.

Os diversos esforços envidados pela TV Justiça, coordenada pela Assessoria de Comunicação do Supremo Tribunal Federal, incontestavelmente, consubstanciam a orientação institucional do Poder Judiciário brasileiro de, tanto quanto o possível, maximizar a transparência em suas atividades, tal como asseveraram em algumas oportunidades porta-vozes do Conselho Nacional de Justiça. ${ }^{10}$

\section{O REGRAMENTO NORMATIVO E O INCIPIENTE DEBATE SOBRE A TRANSMISSÃO DAS SESSÕES DE JULGAMENTO DO SUPREMO TRIBUNAL}

Embora a prática de transmitir integralmente e ao vivo as sessões plenárias do Supremo Tribunal Federal já tenha se arraigado na cultura jurídica e nos costumes forenses que regem o cotidiano do Supremo Tribunal Federal, inexiste no ordenamento jurídico brasileiro dispositivo normativo específico que regulamente de forma direta a práxis de maximização da transparência.

Concretamente, ela tem se realizado a partir da densificação de normas-princípios que consagram, em termos genéricos, o dever de publicidade para a atuação do Poder Judiciário 
e garantem o direito fundamental à informação. Com efeito, apesar de, em 2002, haver sido promulgada a Lei $n^{\circ}{ }^{\circ} 10.461$, esse instrumento normativo teve por finalidade específica, tão somente, acrescer a alínea $h$ à Lei n. ${ }^{\circ}$ 8.977/95, para disponibilizar "um canal reservado ao Supremo Tribunal Federal, para a divulgação dos atos do Poder Judiciário e dos serviços essenciais à Justiça." (BRASIL, 1995, online).

Nem essa lei, nem qualquer outro ato normativo detalhado, foram editados posteriormente pelo Poder Legislativo, ou pelo Supremo Tribunal Federal, para regulamentar especificadamente a transmissão das sessões desse Tribunal pelos meios de comunicação de massa.

Percebe-se, por conseguinte, existir uma lacuna no ordenamento jurídico nacional sobre a regulamentação da prática. Entrementes, a inexistência de ato normativo detalhado com o escopo de regulamentá-la não permite que nos aproximemos da conclusão precipitada de que as transmissões sejam ilegais ou inconstitucionais.

Irrefutavelmente, diversos dispositivos constitucionais e infraconstitucionais do ordenamento jurídico brasileiro consagram a publicidade dos atos processuais e jurisdicionais como regra jurídica e instituem o sigilo como exceção condicionada a circunstâncias especiais.

Nesse sentido, o artigo 124 do Regimento Interno do Supremo Tribunal Federal dispõe que: "As sessões serão públicas, salvo quando este Regimento determinar que sejam secretas, ou assim o deliberar o Plenário ou a Turma" (BRASIL, 1980, online), do que se denota que a Suprema Corte, em norma de organização interna, ratifica o mandamento constitucional existente em favor da ampla publicidade dos julgamentos realizados pelo Poder Judiciário constante no inciso IX do art. 93 da Constituição Federal.

Também o Código de Processo Civil brasileiro, nos artigos 8 , 11, 189 e 368 (BRASIL, 2015), homenageia o princípio da publicidade dos atos jurisdicionais, ao prescrever a regra de que todos os atos processuais são públicos, salvo aqueles em que o interesse público exigir, ou cuja matéria aborde assuntos de direito de família ou de arbitragem, em orientação que evidencia a diretriz principiológica do ordenamento em favor da ampla publicidade dos atos processuais.

Importa inclusive ressaltar que a Constituição veda ao legislador infraconstitucional a possibilidade de restringir a publicidade dos atos processuais, a não ser em situações excepcionais, conforme se denota da dicção literal do inciso LX do art. $5^{\circ}$ da Lei Fundamental, que dispõe: "a lei só poderá restringir a publicidade dos atos processuais quando a defesa da intimidade ou o interesse social o exigirem." (BRASIL, 1988, online).

Nesse arcabouço normativo, em que normas de hierarquia constitucional e infraconstitucional consagram a publicidade dos atos judiciais como princípio condutor das atividades jurisdicionais, a questão da não regulamentação da transmissão das sessões de julgamento do Supremo Tribunal Federal - por dispositivo específico do tipo regra - apresenta-se mais como um problema de segurança jurídica do que como um problema de ilegalidade ou inconstitucionalidade da práxis. 
No entanto, longe de encontrar unanimidade, a discussão sobre a exibição dos julgamentos realizados pelo Supremo Tribunal Federal, por intermédio da mídia, tem se apresentado em matizes passionais, havendo pouco consenso sobre a pertinência jurídica da prática.

Nacionalmente, a maioria das abordagens tem se dado de maneira perfunctória, predominantemente, em entrevistas dadas por consagrados juristas a jornais ou em publicações feitas em periódicos não especializados. Embora a enunciação desses posicionamentos sirva para ilustrar a existência de diferentes pontos de vista sobre o uso constitucional, não cumpre com o desiderato de aprofundar, por um viés científico, nos problemas pertinentes ao tema.

Isso porque, como se observa, a doutrina tem relegado a segundo plano a necessidade de examinar a relação entre a pertinência do regime de publicidade dos processos submetidos à Corte com a natureza jurídica das respectivas competências exercidas pelo Tribunal. ${ }^{11}$

Quando questionados(as) sobre a pertinência e/ou virtuosidade da prática adotada pelo Supremo Tribunal Federal de transmitir integralmente e ao vivo os julgamentos realizados pelo Plenário da Corte, conceituados(as) juristas e magistrados(as) brasileiros(as) têm elogiado a iniciativa do Tribunal de maneira genérica.

Neste sentido, Binenbojm argumenta que:

A defesa da Constituição é tarefa por demais importante para ficar aprisionada às quatro paredes do claustro judicial; se interpretar o sentido das normas constitucionais é algo decisivo para a definição dos direitos e deveres mais fundamentais dos cidadãos, todos os membros da coletividade devem ter o direito - na maior medida possível - de conhecer os porquês das decisões do Supremo Tribunal Federal (BINENBOJM, 2009, online).

Observa-se que, na visão desse eminente jurista, os fundamentos argumentativos das decisões exaradas pelo Supremo Tribunal Federal devem ser publicizados para a população, na maior medida possível, a fim de legitimarem as decisões com mais respaldo democrático.

Em sentido semelhante, Oscar Vilhena Vieira também ressalta a virtuosidade da prática adotada de forma pioneira pelo Supremo Tribunal Federal. De acordo com o respeitado professor da Fundação Getúlio Vargas: "Todo televisionamento de encontros públicos são saudáveis; Ainda mais no Brasil, país tão pouco transparente nas coisas públicas. Uma das instâncias de soberania decidindo em público é algo valoroso e temos que incentivar." (HENRIQUES, 2009, online).

Levando em conta a sensação popular de que, no Brasil, os assuntos públicos são tratados de forma pouco transparente, o jurista ressalta que a iniciativa de transmitir ao vivo e integralmente as sessões de julgamento do STF contribui, consideravelmente, para aprimorar a experiência democrática no país.

Enfaticamente, alinhado com o posicionamento manifestado pela Ordem Nacional dos Advogados do Brasil, Francisco de Paula Bernardes Junior afirma que:

Noutros tantos benefícios de se transmitir ao vivo os julgamentos está uma 
questão primordial para a democracia: a transparência, as luzes que se colocam sobre os atos judiciais mais importantes e o consequente alto grau de legitimidade que incide sobre todas as decisões emanadas pelos membros da mais alta corte do País. Isso sem contar o benefício da aproximação entre o distante Poder Judiciário e o povo (BERNARDES JÚNIOR, 2009, p. 14).

Ainda, o nobre causídico ressalta que as transmissões ao vivo e integrais das sessões do Supremo, ao permitirem contato direto dos estudantes com as deliberações do órgão, ampliam as suas possibilidades de obterem conhecimentos técnicos, fato que provoca diversos efeitos positivos para a democracia constitucional e para o direito (BERNARDES JÚNIOR, 2009).

Seguindo a mesma diretriz, a ex-ministra do Supremo Tribunal Federal, Ellen Gracie, quando questionada se é positivo que as sessões do Supremo sejam transmitidas ao vivo e integralmente pela TV, em entrevista, disse que:

[...] os benefícios da televisão estão claros. Ela dá grande transparência à Justiça. Essa transparência é importante, não é possível regredir. Durante a minha presidência, discutimos a possibilidade de editar as sessões. Mas aí ficamos com um problema seríssimo: quem faria essa edição? Quem haveria de cortar a palavra deste ou daquele ministro? Mantivemos o formato, que está bem aceito pela comunidade jurídica. Mesmo que às vezes deixe os ministros muito expostos (GRACE, 2011, online).

É de se destacar nas palavras proferidas pela magistrada aposentada que a opção pela transmissão das sessões da Corte, de modo integral, permite aos telespectadores terem uma visão fidedigna do que ocorre nas suas deliberações, e assim, não admite que os acontecimentos ocorridos sejam submetidos a edições capazes de manipulá-los.

Em orientação favorável à irrestrita publicização das sessões, também se manifesta o ex-ministro do Supremo Tribunal Federal, Carlos Ayres Britto, para quem: "A democracia tem na visibilidade, na transparência e na plenitude da informação um dos seus pilares mais sólidos e vistosos. Para mim, transmitir ao vivo as sessões do Supremo é um avanço democrático e corresponde a uma viagem sem volta." (RONCAGLIA, 2008, online).

O mesmo ponto de vista é compartilhado pelo ministro do Supremo Tribunal Federal, Gilmar Mendes, para quem a transmissão direta dos debates e dos julgamentos no STF é "uma experiência que tem servido de modelo para outros países [...]" (CRUZ, 2010, p. 3). Em consonância com outros doutrinadores, o magistrado considera positiva a exposição das deliberações jurisdicionais da Corte como forma de otimizar-se a transparência do órgão.

Contrariamente, conceituados mestres do direito brasileiro têm criticado a práxis por compreenderem, em síntese, que uma irrestrita publicidade das sessões do órgão não resulta necessariamente na maximização de sua transparência e, tampouco, em uma melhor concretização do ideário de publicidade em Estado Democrático de Direito. Nesse sentido, Dalmo de Abreu Dallari enfatiza, categoricamente, que:

A experiência que já se tem da transmissão ao vivo - ou, segundo a gíria dos meios de comunicação, da transmissão em tempo real - das sessões do Supremo Tribunal Federal deixa mais do que evidente que essa prática deve ser imediata- 
mente eliminada, em benefício da prestação jurisdicional equilibrada, racional, sóbria, inspirada nos princípios jurídicos fundamentais e na busca da Justiça, sem a interferência nefasta de atrativos e desvios emocionais, ou de pressões de qualquer espécie, fatores que prejudicam ou anulam a independência, a serenidade e a imparcialidade do julgador (DALLARI, 2014, online).

Denota-se da crítica efetuada pelo ilustre juspublicista que, em sua visão, a prática de transmitirem-se os julgamentos do Supremo Tribunal Federal expõe, desnecessariamente, os ministros do Tribunal a pressões externas e a ambientes de exibicionismo não compatíveis com a função jurisdicional.

De uma forma um pouco menos incisiva, Virgílio Afonso da Silva e Conrado Hübner Mendes criticam a ideia de que a transmissão integral e ao vivo das sessões de julgamento do Supremo Tribunal Federal implique, necessariamente, na otimização dos princípios da publicidade e de transparência. Os constitucionalistas asseveram que:

Transmissões ao vivo e acórdãos disponíveis na internet, entre outras medidas, criaram um mito de transparência que precisa ser desconstruído. Ao contrário do que muitos tentam fazer crer, publicidade e transparência não têm nenhuma relação direta e necessária com a quantidade de julgamentos transmitidos pela TV. Um tribunal constitucional transparente é aquele que decide com base em argumentos transparentes, que não disfarça dilemas morais por trás de retórica jurídica hermética, que não se faz surdo para os argumentos apresentados pela sociedade. Em suma, é aquele que expõe abertamente os fundamentos de suas decisões para que sejam escrutinados no debate público (SILVA; MEDES, 2009, online).

Com a perspicácia habitual, os doutrinadores advertem que, com a prática, talvez "a título de uma sedutora transparência de superfície", esteja-se a produzir "um indesejável populismo judicial." (SILVA; MEDES, 2009, online).

Ainda, também de forma fundamentada, José Miguel Garcia Medina critica o fato de que a ampla exposição dos julgamentos do plenário do Supremo Tribunal Federal estimula a alterações no desempenho dos seus magistrados, já que, com as transmissões, eles passariam a preocupar-se, exageradamente, com as suas imagens. Segundo o professor:

Ciente da repercussão que sua atuação terá - não apenas em relação às partes ou aos demais atores institucionais (como, p.ex., os legisladores) -, o juiz cuida de sua própria performance, do modo como se porta (gestos, entonação de voz) ao transmitir suas ideias etc. Há o risco, assim, [com as transmissões ao vivo e integrais das sessões] de preponderar, na atuação do magistrado, uma maior preocupação com a imagem que é transmitida de si mesmo que com a substância do que está sendo julgado. Parece que estão certos aqueles que afirmam que isso repercute na qualidade, no conteúdo e na extensão dos votos dos ministros (MEDINA, 2014, online).

Adversamente às transmissões, igualmente já se manifestou o ministro aposentado, Eros Roberto Grau, para quem a tomada de decisões pelos magistrados em processos é "um momento de grande intimidade" (RODRIGUES, 2009, online), cuja substância está devassada com a transmissão das sessões pelos meios de comunicação. 
No mesmo sentido é o posicionamento de Carlos Mário da Silva Velloso, também ministro aposentado da Corte, que entende que a transmissão integral dos julgamentos não é bem quista para a imagem do Tribunal e, tampouco, para a República. De acordo com o ilustre jurista:

Expor debates da corte na TV Justiça é excelente, mas depois de editados, como acontece com os grandes programas de televisão. Ao vivo, não me parece bom. A sociedade espera dos juízes comportamento moderado, equilibrado. Todavia, vale repetir, os juízes são seres humanos, não são anjos e estão sujeitos a exasperações nem sempre bem compreendidas pelo homem comum. Pessoas, muitas vezes movidas por posições ideológicas, tomam partido em favor de um ou de outro dos juízes, vulgarizando o debate judicial (VELLOSO, 2009, online).

Em sentido semelhante, e criticando a ampla exposição a que se submetem os magistrados, o falecido e notório ministro do Colendo Tribunal, Teori Zavascki, destacava de forma análoga que as transmissões:

Tem pontos positivos e negativos. Um ponto negativo é o excesso de exposição que às vezes não colabora para um julgamento tranquilo, sereno. Para o meu gosto, acho que se poderia repensar isso. Não sou contra a publicidade dos atos, que são públicos por imposição constitucional. Mas entre publicidade e transmissão ao vivo tem um meio caminho (GALLUCCI, 2012, online).

\section{ANECESSIDADEDEAVALIARAPRÁTICAEMCORRESPONDÊNCIACOM ANATUREZA JURÍDICA DAS RESPECTIVAS COMPETÊNCIAS JURISDI- CIONAIS}

O debate doutrinário acerca da virtuosidade da prática adotada pelo Supremo Tribunal Federal de abrir as sessões de julgamento do Plenário do órgão, para transmissão ao vivo e integral por meio de canais midiáticos, embora incipiente e ainda pouco aprofundado, evidencia que o tema é polêmico e que um consenso sobre o assunto é difícil.

Os motivos que dificultam a edificação de uma ampla concordância sobre a temática estão associados à própria existência de um considerável dissenso no que se refere a qual é o significado e qual é o alcance dos princípios da publicidade e da transparência para os poderes constituídos da República. Ademais, grandes dúvidas pairam sobre como esses princípios devem ser concretizados nos diferentes tipos de atos jurisdicionais praticados pelo Judiciário.

Como a enunciação de diferentes posicionamentos acerca do tema demonstra, não há consentimento, por parte da doutrina, nem de seus magistrados, de que a ampla exposição das sessões de julgamento do STF conduza, necessariamente, à aproximação do órgão com a população e, tampouco, de que a prática se traduza, efetivamente, na otimização dos deveres de publicidade e de transparência das atividades estatais.

Enquanto alguns juristas compreendem a práxis como um instrumento de maximização dos ideários republicanos, outros apreendem nela a instituição de um modelo que fragilizaria 
a prestação jurisdicional dos ministros da Suprema Corte, por lhes deixar mais suscetíveis a indesejáveis influências externas.

O que se percebe é que, apesar de os argumentos lançados por renomados juristas servirem para clarificar e desenvolver o debate acerca da virtuosidade, ou desvalor da prática, a doutrina não tem demonstrado preocupação em examinar a questão por meio de uma abordagem científica, com a qual o mérito e a pertinência da exposição das sessões de julgamento da Corte sejam avaliados, de maneira dogmática, e com observância às peculiaridades das distintas competências jurisdicionais exercidas.

Como é cediço, o Supremo Tribunal Federal brasileiro detém diversas atribuições jurisdicionais que extrapolam as clássicas competências conferidas às cortes constitucionais de acordo com o tradicional modelo europeu. ${ }^{12}$

Para além das funções típicas de jurisdição constitucional relacionadas às competências para julgar litígios envolvendo conflitos entre entes federados, realizar o controle de constitucionalidade de atos normativos e garantir a proteção de direitos fundamentais, cumpre originariamente à Suprema Corte brasileira julgar as infrações penais comuns supostamente cometidas por altas autoridades, o pedido de extradição solicitado por Estado estrangeiro, os conflitos de competência entre os tribunais superiores e outros tribunais, os mandados de segurança, habeas corpus e habeas data contra atos praticados por órgãos da cúpula do Poder, ou por altas autoridades, entre outras espécies de litígios. ${ }^{13}$

É indubitável que, ao concentrar diversas e distintas competências jurisdicionais, o Supremo Tribunal Federal, inevitavelmente, aplica a Constituição em litígios de natureza jurídica material variada (propriamente constitucional, penal, civil, administrativa, internacional) e que esses conflitos são regidos por díspares normas, interesses e procedimentos processuais.

Com base nessa conjuntura normativa, em que ao Supremo Tribunal Federal foram atribuídas competências para julgar processos de naturezas jurídicas eminentemente diversificadas, entende-se ser recomendável que a avaliação valorativa da prática de abertura das sessões de julgamento para transmissão ao vivo e integral se dê com sensibilidade para a natureza das competências jurisdicionais exercidas e de acordo com as peculiaridades de seus ritos processuais.

Isso porque, a depender da competência jurisdicional, entende-se que o dever de transparência dos atos jurisdicionais pode variar em intensidade, assim como a necessidade de proteção à intimidade ou à privacidade, bem como irá variar o procedimento de ponderação dos bens jurídicos e dos interesses conflitantes.

A definição de um posicionamento a favor ou contra a prática depende, preliminarmente, do reconhecimento de que as atividades de jurisdição constitucional realizadas pela Corte possuem distintas naturezas e servem a diversificados propósitos no âmbito do Estado Democrático de Direito, razão pela qual não podem ser analisadas como se fizessem parte de um único grupo homogêneo, como até então tem ocorrido. 
Por meio da jurisdição criminal em sentido lato, seja nas instâncias ordinárias, seja nas cortes constitucionais com competências especiais, almeja-se, em síntese, a aplicação das leis penais aos fatos violadores ou ameaçadores de bens, direitos e valores reconhecidos pela sociedade como de mais alta relevância e dignidade (OLIVEIRA, 2011, p. 203-204).

Enquanto instrumento veiculador da pretensão punitiva estatal ou privada, o processo penal, em Estado Democrático de Direito, deve assegurar aos acusados alguns dos seus direitos fundamentais mais básicos, como a intimidade, a honra e a imagem; ${ }^{14}$ além dos consectários capitais do devido processo legal consubstanciados na ampla defesa, no contraditório, na paridade de armas, entre outros princípios.

A cobertura midiática de processos criminais, tal como significativa doutrina tem asseverado, é capaz de gerar máculas indeléveis à honra, à intimidade e à imagem dos acusados, mesmo quando venham a ser posteriormente absolvidos com o devido transcurso da ação penal de que são parte. ${ }^{15}$

Considerando-se a repulsa e a comoção social que a figura do crime engendra, nota-se que a ampla divulgação na imprensa de fatos e acusações ainda não comprovadas - sejam nas fases investigatórias, instrutórias ou de julgamento - e a veiculação desses julgamentos pelos meios de comunicação, provocam danos à imagem, à honra e à intimidade dos investigados, cuja reparação não poderá ser feita, efetivamente, após a sua exposição para o público.

A conjuntura sensível que envolve os julgamentos e pré-julgamentos criminais, destarte, torna recomendável a adoção de extrema cautela para se otimizar a publicidade e a transparência, nesses juízos, levando-se em conta a necessidade de que os direitos fundamentais dos acusados sejam preservados.

É de se sopesar, ainda, que, nos processos criminais de competência do Tribunal do Júri (art. 5, XXXVIII, 'd') (BRASIL, 1988) o poder midiático é capaz de influenciar excessivamente o veredito dos jurados. Como os indivíduos que o compõem, em regra, não são tecnicamente preparados, tal como são os juízes togados, para remanescerem imparciais diante de pressões externas, os riscos de violação à higidez e ao transcurso do devido processo legal podem ser ainda mais exacerbados nessas hipóteses. ${ }^{16}$

Por outro lado, litígios jurídicos de diferentes naturezas materiais (eleitoral, trabalhista, administrativo, internacional, entre outras) também podem fazer parte dos distintos róis de competências das cortes constitucionais. ${ }^{17}$ Para que um juízo de pertinência sobre a exposição dessas competências a modelos de otimização de publicidade seja realizado, é imprescindível que os variados bens e interesses jurídicos, eventualmente em conflito, sejam sopesados, casuisticamente.

Considerando-se a existência de distintos bens jurídicos e interesses nos mais diversos procedimentos exercidos pelas cortes constitucionais, como questões de soberania nacional em litígios envolvendo o pedido de extradição de estrangeiros, questões de preservação da igualdade de condições entre os candidatos em litígios envolvendo campanhas eleitorais, questões de segurança nacional em litígios envolvendo matéria militar, entre outros, o assentamento de posicionamentos, em abstrato, acerca da virtuosidade da submissão destas, e de 
outras competências, a modelos otimizados de publicidade depende da análise pormenorizada sobre o peso que os bens jurídicos conflitantes assumirão nessas circunstâncias.

Desse modo, para se argumentar, abstratamente, sobre a adequação da preponderância de regimes de ampla transparência para as diversas competências usualmente exercidas pelo Supremo Tribunal Federal, faz-se necessário examinar, para cada uma delas, os bens jurídicos e interesses que porventura entrarão em choque, tal como fizemos, sucintamente e de maneira não extenuante, em relação às competências materialmente de direito penal.

Somente a partir desse exercício dogmático, criterioso e ponderativo, torna-se razoável a enunciação de regras gerais capazes de atender às demandas por segurança jurídica, direito à informação e publicidade, sem que outros direitos fundamentais e interesses fiquem aniquilados por uma dogmática monodimensional. ${ }^{18}$

Por fim, cumpre enfatizar que as discussões sobre a constitucionalidade de atos normativos, em sede prejudicial nas ações concretas, ou em sede principal nas ações concentradas, em regra, não perpassam em seu cerne por questões atinentes a direitos de personalidade das partes capazes de justificarem a adoção de regimes de sigilo para salvaguardarem garantias individuais. ${ }^{19}$

Assumida a premissa de que as questões de inconstitucionalidade suscitadas em sede de fiscalização concreta consistem em questões prejudiciais, passíveis de serem examinadas apartadamente do litígio principal a que estão vinculadas, ${ }^{20}$ tal como ocorre em sede abstrata, é absolutamente possível discutirem-se as questões de (in)constitucionalidade sem adentrarem-se em questões subjetivas das partes.

Como nas ações concretas as questões de constitucionalidade podem ser discutidas sem que informações íntimas dos sujeitos sejam divulgadas e, nas ações abstratas-objetivas, ${ }^{21}$ inexistem fatos personalíssimos capazes de justificar a adoção de regimes de sigilo, o evidente interesse público nos procedimentos de controle de constitucionalidade das normas recomenda a adoção de amplos regimes de publicidade e transparência para o seu exercício.

Como é cediço, as decisões proferidas pelas cortes constitucionais possuem incomensurável relevância para a ordem jurídica e política dos Estados nos quais estão inseridas. No exercício do controle abstrato de constitucionalidade de normas infraconstitucionais, as decisões emanadas por esses órgãos, em regra, tangenciam imediatamente o interesse público de todos os sujeitos da sociedade em razão dos efeitos erga omnes usualmente delas provenientes. ${ }^{22}$

Em controle abstrato de constitucionalidade, no Brasil, é o que se afere literalmente com a dicção do $\S 2^{\circ}$ do art. 102 da Constituição Federal, ao prever que as decisões definitivas de mérito proferidas nas ações diretas de inconstitucionalidade e de declaração de constitucionalidade: "produzirão eficácia contra todos e efeito vinculante, relativamente aos demais órgãos do Poder Judiciário e à administração pública direta e indireta, nas esferas federal, estadual e municipal" (BRASIL, 1988, online). Ademais, nos procedimentos de Arguição de Descumprimento de Preceito Fundamental, é o que se extrai da redação do $\$ 3^{\circ}$ do art.

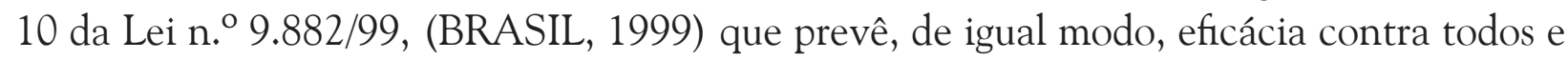
efeito vinculante para os acórdãos neles proferidos. 
Nas decisões proferidas em Ação Direta de Inconstitucionalidade por Omissão, uma vez reconhecida a inconstitucionalidade e a mora do Legislativo para concretizar o dever de legislar, a jurisprudência brasileira admite a possibilidade de a Corte Suprema fixar prazo para que o legislador colmate a lacuna normativa existente. ${ }^{23}$ Nas decisões proferidas em Mandado de Injunção, os acórdãos mais recentes da Corte, inclusive, admitem que o órgão regulamente, provisoriamente, matérias pendentes de conformação pelo legislador, dando-lhes efeitos tipicamente aditivos/normativos. ${ }^{24}$

No que diz respeito às decisões proferidas em controle concreto de constitucionalidade, além de servirem genericamente como precedentes de orientação para diversos tribunais e juízos do Poder Judiciário, elas também podem ganhar características vinculativas, de generalidade e abstratividade, e, assim, os seus efeitos podem repercutir na esfera jurídica de diversos indivíduos da comunidade. ${ }^{25}$

Nessa toada, em razão dos efeitos de generalidade, vinculatividade e, em alguns casos, normatividade que as decisões jurisdicionais do Supremo Tribunal Federal podem adquirir, o reclame por ampla transparência nas sessões de julgamento em que se estejam praticando atos de fiscalização de constitucionalidade é verdadeiro imperativo da ordem jurídica em consonância com os fundamentos republicanos do Estado Democrático de Direito.

\section{CONCLUSÃO}

A prática de submeter as sessões de julgamento do Supremo Tribunal Federal a um grau otimizado de publicidade, atualmente, adstringe-se às sessões de competência do Plenário e, portanto, não abrange as sessões realizadas pelas Turmas desse Tribunal. Consequentemente, dois regimes de transparência têm coexistido nas decisões proferidas pelos órgãos colegiados da Corte com graus de accountability diversos.

Hodiernamente, o critério que define que somente as sessões plenárias do Tribunal devem se submeter ao regime otimizado de publicidade não está regulamentado em nenhum ato normativo do ordenamento jurídico e se consolidou na cultura jurídica nacional por meio da simples repetição de um uso. Além de ser censurável que o uso não seja regulamentado por nenhum dispositivo específico, é despropositado o critério empregado para eleger os regimes de publicidade das respectivas competências, já que leva em consideração somente os aspectos relativos à organização interna do Tribunal e desconsidera as suas particularidades.

Embora atualmente as ações concentradas de constitucionalidade sejam de competência do Plenário (art. 5. ${ }^{\circ}$, VII, do RISTF) (BRASIL, 1980), o Tribunal pode transferir competências deste para as Turmas, e das Turmas para o Plenário, simplesmente por meio de alterações regimentais em consonância com a dicção do art. 96, I, 'a', da CF/88 (BRASIL, 1988). Com isso, o regime de publicidade dos processos segue acessoriamente o regime de publicidade do órgão competente para julgá-los. Seria mais acertado que o regime fosse fixado 
de acordo com a natureza jurídica das competências e com consideração para os interesses jurídicos abstratamente envolvidos nas lides.

Com efeito, o fato de inexistir dispositivo normativo que regulamente pormenorizadamente a prática contribui para um ambiente de insegurança jurídica, incapaz de garantir uma pretensão legítima para os indivíduos e para a coletividade, de reivindicar, para certas e determinadas competências, um direito subjetivo ao regime de publicidade mais adequado a sua correspondente natureza processual. É essencial que o legislador, ou a Corte, avancem na regulamentação da matéria.

Na ausência de critérios definidos por lei, o juízo de pertinência sobre quais competências devem estar submetidas a um critério amplo, ou restrito, de transparência deve ser feito com responsabilidade e atenção para os bens jurídicos e interesses envolvidos.

Independentemente se proferidas em fiscalização abstrata ou concreta, o que a realidade do ordenamento jurídico brasileiro evidencia é que as decisões proferidas pelo Supremo Tribunal Federal, em controle de constitucionalidade, têm se revestido de características tipicamente normativas, uma vez que:

a) podem produzir efeitos contra todos, originariamente ou por abstrativização;

b) podem vincular a interpretação dos órgãos do Judiciário e da Administração Pública e;

c) podem normatizar situações não regulamentadas pelo legislador nas excepcionais sentenças aditivas.

Assim sendo, é essencial que os procedimentos de fiscalização de constitucionalidade praticados pela Corte sucedam com ampla publicidade, tal como tem ocorrido com o intermédio dos meios de comunicação de massa. Indubitavelmente, permitir que os indivíduos acedam à forma e aos argumentos por meio dos quais os guardiões da Constituição invalidam as normas aprovadas pelos seus representantes, trata-se, efetivamente, de um postulado material do Estado Democrático de Direito em consonância com o apropriado exercício da função contramajoritária.

\title{
THE MEDIA TRANSMISSIONS OF JUDGMENT SESSIONS OF THE BRAZILIAN SUPREME COURT
}

\begin{abstract}
This paper examines the history, the objectives, the policies, and the debate in Brazilian legal doctrine about the innovative practice adopted by the Brazilian Supreme Court to allow the live and full transmission of part of its trial sessions through the media. In order to clarify the various controversies related to the novel institute, intended to guarantee the right to information - in a dogmatic manner -, it is recommended to evaluate the practice by considering, in particular, the singularities and legal nature of the jurisdictional competences assigned by the Constitution to the Federal Supreme Court.
\end{abstract}


Keywords: Brazilian Supreme Court. Court TV. Constitutional Jurisdiction. Law \& Society. Right to Information.

\section{LAS TRANSMISIONES MIDIÁTICAS DE LAS SESIONES DE JUZGAMIENTO DEL SUPREMO TRIBUNAL FEDERAL}

\section{RESUMEN}

Se examinan en este trabajo la historia, los objetivos, el reglamento normativo y el debate existente en la doctrina jurídica brasileña sobre la innovadora práctica adoptada por el Supremo Tribunal Federal de permitir la transmisión en vivo e integral de parte de sus sesiones de juzgamiento por los medios de comunicación en masa. A fin de aclarar las diversas controversias relacionadas al instituto garantizador del derecho a la información - de manera dogmática - se recomienda la evaluación de la práctica, considerándose, especificadamente, las singularidades y la naturaleza jurídica de las competencias jurisdiccionales atribuidas por la Constitución de la República al Supremo Tribunal Federal.

Palabras-clave: Supremo Tribunal Federal. TV Justicia. Jurisdicción Constitucional. Derecho y Sociedad. Derecho a la Información.

1 Vide Resolução do Supremo Tribunal Federal n. ${ }^{\circ} 232$ de $1^{\circ}$ de julho de 2002.

2 Cf. Exposição de Motivos do Projeto de Lei n. ${ }^{\circ}$ 6.059/02. (BRASIL, 2002).

3 Cf. Monteiro (2011); Barros, Bernardes e Rehbein (2015, p. 183-221).

4 Cf. Santos (2007, p. 34).

5 De acordo com dados fornecidos pelo Instituto Brasileiro de Geografia e Estatística (IBGE) em Pesquisa Nacional por Amostra de Domicílios (PNAD) realizado no ano de 2004, a maior parte da população brasileira tinha, à época, como instrumentos predominantes de acesso à mídia eletrônica, o Rádio e a Televisão. Pelos dados prestados, os percentuais de domicílios que possuíam os respectivos aparelhos de mídia eram os seguintes: Rádio: 88\%; Televisão: 90\%; Computador: 16\%; Acesso à Internet: 12\%. Cf. Azevedo (2006, p. 31).

6 Cf. Machado (2013, p. 42).

7 Cf. Lages (2012, p. 185-191).

8 Cf. Alves e Fiuza (2002, p. 40).

9 Para uma lista completa dos programas da TV Justiça, consultem-se as informações fornecidas no site da emissora. (TV JUSTIÇA, 2017b).

10 A preocupação do Poder Judiciário brasileiro com a transparência e a publicidade de suas ações é hoje uma diretriz institucional do Conselho Nacional de Justiça $(\mathrm{CNJ})$. Merece destaque a declaração dada pela Ministra do Superior Tribunal de Justiça, ELIANA CALMON, em fevereiro de 2013, no Encontro Nacional de Comunicação do Poder Judiciário em Brasília, na qual destacou que "a transparência é a palaura de ordem do Século 21". (CONSELHO NACIONAL DE JUSTIÇA, 2017).

11 A responsabilidade pelo tratamento superficial dada ao tema pode ser compartilhada tanto pelos meios de comunicação como pela doutrina: Aqueles, por não terem conseguido aclarar o debate e lançar as indagações necessárias que precisam ser respondidas sobre a prática, como a inexistência de dispositivo expresso que a regulamente ou a discussão sobre a relação entre o regime de transparência e a natureza das competências jurisdicionais. A doutrina, por ter dedicado, até então, pouquíssimos trabalhos científicos destinados a examinar 
o tema com profundidade. É de se destacar que a maioria dos posicionamentos sobre a temática, divulgados nos meios de comunicação, afloraram na época do julgamento da Ação Penal 470 (conhecida popularmente como "Mensalão"), conjuntura que acabou exaltando a polêmica sobre a presença de câmeras de TV no exercício da jurisdição penal, sem o devido aprofundamento das suas repercussões no exercício de outras competências jurisdicionais.

12 Cf. Moraes (2013, p. 210-214).

13 Competências taxativamente descritas no art. 102 da Constituição Federal da República.

14 A primeira, compreendida como a garantia que assegura "o direito do indivíduo de não ser importunado pelos meios de comunicação, de se manter afastado da curiosidade pública, bem como [a garantia que] impede indiscrições na divulgação de fatos ocorridos ou atos realizados no âmbito mais restrito de sua vida privada e íntima. A segunda como o "valor pessoal originário da dignidade do ser humano, que reflete socialmente e faz com que o indivíduo usufrua do respeito adquirido na comunidade." Portanto: "o conjunto de qualidades que exornam a pessoa humana, conferindo-lhe respeitabilidade social e estima própria."”; e a última como o "[...] bem jurídico autônomo e independente da intimidade, privacidade e honra. [...] 'é a projeção da personalidade física (trações fisionômicos, corpo, atitudes, gestos, sorrisos, indumentárias etc.) ou moral (aura, fama, reputação etc.) do indivíduo (homens, mulheres, crianças ou bebê) no mundo exterior."' Conforme Vieira (2003, p. 147-151).

15 Sobre o tema, vide (VOENA, 1984; ALMEIDA; GOMES, 2013;. DI CHIARA, 1998; ANDRADE, 2007), entre outros.

16 Consoante Ana Lúcia Menezes Vieira (VIEIRA, 2003, p. 246): "A publicidade prévia de fato criminoso ou dos atos do desenvolvimento processual pelos meios de comunicação, perante os casos de competência do Tribunal do Júri, é particularmente preocupante, pois, uma vez que o julgamento é feito por juízes leigos, a impressão que a mídia transmite do crime e do criminosos produz maior efeito neles do que as provas trazidas pelas partes na instrução e julgamento no plenário. O jurado, 'cidadão incumbido pela sociedade de declarar se os acusados submetidos a julgamento são culpados ou inocentes', é mais permeável à opinião pública, à comoção que se criou em torno do caso em julgamento, do que os juízes togados e, por sentirem-se pressionados pela campanha criada na imprensa, correm o risco de se afastarem do dever da imparcialidade e acabam julgando de acordo com o que foi difundido pela mídia."

17 A jurisdição constitucional pode ser magistralmente conceituada como a totalidade de atividades judiciais de aplicação da Constituição, conforme Reyes (2009, p. 237-238). Havendo diversos tipos de competências jurisdicionais que podem ser atribuídas a uma Corte constitucional, não é possível enunciarem-se, exaustivamente, todos os tipos de conflitos que podem estar sujeitos à tutela desses órgãos.

18 Embora, politicamente, a realização da publicidade seja regra; e o sigilo, exceção nos Estados Democráticos de Direito, em termos jurídicos, os Estados não podem ser a priori forçados a publicizar com transparência todos os seus atos, eis que, em certas situações, é necessário efetuar-se uma ponderação de valores que poderá resultar na preponderância dos interesses da proteção do sigilo e do resguardo de outras garantias. A propósito, vide os desenvolvimentos sobre a ponderação elaborados por Garcia (1984, p. 415-435) e por Casanova (2004, p. 876-884).

19 Como leciona Carlos Blanco de Morais (MORAIS, 2014, p. 659): "Mesmo em sede de controlo concreto, onde o contexto inerente a um caso singular releva com maior pragnância em termos interpretativos, a interpretação recai sobre a norma constitucional e sobre a norma ordinária aplicada ou desaplicada por um tribunal comum." Isto implica dizer que, para a resolução das questões constitucionais, em controle concreto, os juízes constitucionais não precisam adentrar necessariamente nas peculiaridades subjetivas da demanda principal, mesmo nas ordens jurídicas em que o órgão que soluciona o incidente constitucional examina também o mérito do processo concreto. Consequentemente, é possível que os debates concernentes ao conflito entre normas possam ser publicizados sem a necessária exposição do litígio a ele relacionado.

20 Consoante os ensinamentos do Professor da Faculdade de Lisboa, tal como tem sido sustentado na doutrina brasileira e portuguesa, sem exceção de algumas divergências (MORAIS, 2011, p. 609): "a questão de inconstitucionalidade suscitada em sede de fiscalização concreta consiste numa questão prejudicial surgida no âmbito de um processo principal, no qual se encontra a ser julgado um determinado pleito."

21 Cf. Tavares (2010, p. 266-278). "Em síntese, o caráter abstrato do processo objetivo afasta a aplicação plena das regras processuais 'comuns', vale dizer, daquelas próprias dos processos nos quais se discutem situações subjetivas. No caso do processo objetivo não se preocupa o Tribunal Constitucional com qualquer situação 
concreta que, ademais, nem sequer existe no seio do referido processo. Ocupa-se exclusivamente da regularidade da ordem constitucional." (Idem, p. 267).

22 No Brasil, consoante a diç̧ão do $\S 2^{\circ}$ do art. 102 da CF/88 e $\S 3^{\circ}$ do art. 10 da Lei n..$^{\circ}$ 9.882/99.

23 Vide a ADI n. ${ }^{\circ}$ 3682, julgada em 09/05/2007.

24 Vide, exemplificativamente, o Mandado de Injunção n. ${ }^{\circ}$ 758, jugado em 01/07/2008.

25 Após a EC n. ${ }^{\circ}$ 45/2004, a Constituição brasileira (art. 103-A) passou a conferir ao Supremo Tribunal Federal a capacidade para atribuir efeitos de natureza vinculante às decisões por ele proferidas também em fiscalização concreta de constitucionalidade, com a criação das famigeradas súmulas vinculantes. Uma vez editados esses instrumentos, as hipóteses exegéticas dos demais órgãos do Poder Judiciário e da Administração Pública passam a estar atreladas aos entendimentos constitucionais fixados pelo Tribunal Supremo por meio dessas súmulas. No direito comparado, cf. (PERGORARO, 2015, p. 57-105; SOTELO, 1998, p. 374; SEGADO, 2004, p. 143-208).

\section{REFERENCIAS}

ALMEIDA, Débora de Souza de; GOMES, Luiz Flávio. Populismo penal midiático: caso mensalão, mídia disruptiva e direito penal crítico. São Paulo: Saraiva, 2013.

ALVES, Léo da Silva; FIUZA, Tatiana. No ar, a TV Justiça. Consulex, Brasília, v. 6, n. 130, jun. 2002.

ANDRADE, Fábio Martins de. Mídia e poder judiciário: a influência dos órgãos da mídia no processo penal brasileiro. Rio de Janeiro: Lumen Juris, 2007.

AZEVEDO, Fernando Antônio. Democracia e mídia no Brasil: um balanço dos anos recentes. In: GOULART, Jefferson O. (Org.). Mídia e democracia. São Paulo: Annablume Editora, 2006.

BARROS, Antonio Teixeira de; BERNARDES, Cristiane Brum; REHBEIN, Malena. O parlamento brasileiro e as novas mídias: balanço da experiência recente da Câmara dos Deputados. In: BRAGA, Ricardo; SATHLER, André (Org.). Legislativo pós-1988: reflexões e perspectivas. Brasília: Edições Câmara, 2015.

BERNARDES JÚNIOR, Francisco de Paula. É a favor da transmissão ao vivo de julgamentos do STF? O Estado de São Paulo, São Paulo, p. A14, 20 maio 2009.

BINENBOJM, Gustavo. A Justiça na TV. Folha de São Paulo, São Paulo, p. A3, 2 maio 2009. Disponível em: <http://www1.folha.uol.com.br/fsp/opiniao/fz0205200909.htm>. Acesso em: 10 maio 2017.

BRASIL. Supremo Tribunal Federal. 120 anos do Supremo Tribunal Federal. Disponível em: <http://www2.stf.jus.br/portalStfInternacional/cms/verConteudo. php? sigla $=$ portalStfSobreCorte_pt_br\&idConteudo $=196222 \&$ modo $=\mathrm{cms}>$. Acesso em: 10 maio 2017.

. Regimento interno. Texto originalmente publicado no Diário da Justiça de 27 de outubro de 1980. Disponível em: <http://www.stf.jus.br/arquivo/cms/legislacaoRegimentoInterno/anexo/RISTF.pdf>. Acesso em: 10 maio 2017. 
. Câmara dos Deputados. Projeto de Lei n ${ }^{\circ} 6.059$, de 2002. Disponível em: $<$ http:// www.camara.gov.br/proposicoesWeb/prop_mostrarintegra;jsessionid $=$ B4D71B31264FD FF4120C4D30D6C62F5F.proposicoes Web2 codteor $=17583 \&$ filename $=$ Tramitacao -PL+6059/2002>. Acesso em: 10 maio 2017.

. Constituição da República Federativa do Brasil de 1988. Diário Oficial da República Federativa do Brasil, Brasília, DF, 5 out. 1988. Disponível em: <http://www.planalto.gov. br/ccivil_03/constituicao/douconstituicao88.pdf>. Acesso em: 10 maio 2017.

. Lei no 8.977, de 6 de janeiro de 1995. Presidência da República, Brasília, DF, jan. 1995. Disponível em: < http://www.planalto.gov.br/ccivil_03/leis/L8977.htm>. Acesso em: 10 maio 2017.

. Lei $\mathrm{n}^{\mathrm{O}} 9.868$, de 10 de novembro de 1999. Dispõe sobre o processo e julgamento da ação direta de inconstitucionalidade e da ação declaratória de constitucionalidade perante o Supremo Tribunal Federal. Diário Oficial da República do Brasil, Brasília, DF, 10 nov. 1999.

. Lei $\mathrm{n}^{\mathrm{o}} 13.105$, de 16 de março de 2015. Código de Processo Civil. Diário Oficial da República Federativa do Brasil, Brasília, DF, 16 mar. 2015.

CASANOVA, Salazar. Justiça e jornalismo judiciário: perspectivas jurisprudenciais. O Direito, Lisboa, v 136, n. 5, p. 867-896, 2004.

CONSELHO NACIONAL DE JUSTIÇA. Profissional de comunicação é a ponte para aproximar o judiciário do cidadão. Disponível em: <http://www.cnj.jus.br/noticias/ cnj/23714-profissional-de-comunicacao-e-a-ponte-para-aproximar-o-judiciario-do-cidadao-diz-ministra >. Acesso em: 10 maio. 2017.

CRUZ, José. Reformas reduziram volume de processos no STF. Jornal do Senado, Brasília, v. 16, n. 3.212, p. 3, 15 abr. 2010.

DALLARI, Dalmo de Abreu. Publicidade, vedetismo e deslumbramento. Observatório da Imprensa, v. 18, n. 828, 21 jan. 2014. Disponível em: < http://www.observatoriodaimprensa. com.br/news/view/_ed782_publicidade_vedetismo_e_deslumbramento $>$. Acesso em: 10 maio 2017.

DI CHIARA, Giuseppe. Televisione e dibattimento penale: Esperienze e problemi della pubblicità mediata tecnologica in Italia. Il Foro Italiano, v. 121, n. 6, p. 277-288, 1998.

GALLUCCI, Mariângela. Para Teori, mensalão 'expôs' Supremo. Estadão, 28 nov. 2012. Disponível em: <http://politica.estadao.com.br/noticias/eleicoes,para-teori-mensalao-expos-supremo-imp-,966102 >. Acesso em: 10 maio 2017.

GARCIA. Enrique Alonso. La interpretación de la constitución. Madrid: Centro de Estudios Constitucionales, 1984. 
GRACE, Ellen. A ministra que acaba de sair do supremo tribunal federal avalia o papel do judiciário no cumprimento das leis e na manutenção das liberdades e direitos constitucionais . Revista Veja, São Paulo, 2 set. 2011. Entrevista concedida a Carlos Graieb e Paulo Celso Pereira. Disponível em: http://www.transparenciacapixaba.org.br/noticia-detalhe. aspx $?$ idNot $=$ ENTREVISTA + - +ELLEN +GRACIE+NORTHFLEET $>$. Acesso em: 10 maio 2017.

GUSTIN, Miracy Barbosa de Souza; DIAS, Maria Tereza Fonseca. (Re)pensando a pesquisa jurídica: teoria e prática. 4. ed. Belo Horizonte: Del Rey, 2015.

HENRIQUES, Andréia. Único a transmitir sessões ao vivo, STF fica entre transparência e espetáculo. Última Instância, São Paulo, 7 set. 2009. Disponível em: < http://ultimainstancia. uol.com.br/conteudo/noticias/42921/unico $+\mathrm{a}+$ transmitir + sessoes $+\mathrm{ao}+$ vivo + stf + fica + e ntre + transparencia $+\mathrm{e}+$ espetaculo.shtml $>$. Acesso em: 10 maio 2017.

LAGES, Margarida. Os desafios da linguagem jurídica para uma comunicação eficiente. Revista do Tribunal Regional do Trabalho da 3. Região, Belo Horizonte, v. 55, n. 85, p. 169-208, jan./jun. 2012.

MACHADO, Joana de Souza. Luz, câmera, jurisdição: tecnologia de comunicação e o mito da justiça transparente no Brasil. Boletim Centro de Estudos Direito e Sociedade (CEDS), Rio de Janeiro, p. 41-48, jul./set. 2013.

MEDINA, José Miguel Garcia. Juízes do Supremo Tribunal Federal são midiáticos Conjur, 27 jan. 2014. Disponível em: <http://www.conjur.com.br/2014-jan-27/jose-miguel-medina-juizes-supremo-sao-midiaticos\#_ftn1>. Acesso em: 10 maio 2017.

MONTEIRO, Carlos Barros. Para que serve a TV Legislativa no Brasil e no mundo. São Paulo: Editora Biografia, 2011.

MORAES, Alexandre de. Jurisdição constitucional e tribunais constitucionais: garantia suprema da constituição. 3. ed. São Paulo: Atlas, 2013.

MORAIS, Carlos Blanco de. Justiça Constitucional: o direito do contencioso constitucional. 2. ed.. Coimbra: Coimbra Editora, 2011. Tomo II.

MORAIS, Carlos Blanco de. Curso de direito constitucional: teoria da constituição em tempo de crise do Estado Social. Coimbra: Coimbra Editora, 2014. Tomo II. v. 2.

OLIVEIRA, Eugênio Pacelli de. Curso de processo penal. 15. ed. Rio de Janeiro: Lumen Juris, 2011.

PERGORARO, Lucio. Giustizia costituzionale comparata: dai modelli ai sistemi. Torino: G. Giappichelli Editore, 2015.

REYES, Manuel Aragón. Estudios de derecho constitucional. 2. ed. Madrid: Centro de Estudios Políticos y Constitucionales, 2009. 
RODRIGUES, Alexandre. Eros Grau é contra sessões do STF na TV. O Estado de São Paulo, São Paulo, p. A. 14, 20 maio 2009. Disponível em: < http://politica.estadao.com.br/ noticias/geral,eros-grau-e-contra-sessoes-do-stf-na-tv,373649>. Acesso em: 10 maio 2017.

RONCAGLIA, Daniel. Marco Aurélio critica idéia de editar sessão do Supremo. Conjur, 8 set. 2008. Disponível em: <http://www.conjur.com.br/2008-set-08/marco_aurelio_critica_ideia_editar_sessao_stf $>$. Acesso: 10 maio 2017.

SANTOS, Caroline Henriques Mota Balduíno. TV digital: um olhar sobre uma emissora pública: primeiros passos da TV Justiça rumo à era da transmissão e recepção digital. Brasília: Instituto Científico de Ensino Superior e Pesquisa, 2007.

SEGADO, Francisco Fernández. La Justicia constitucional ante el siglo XXI: la progresiva convergencia de los sistemas americano y europeo-kelseniano. Revista Latino-Americana de Estudos Constitucionais, v. 11, n. 4, jul./dez 2004.

SILVA, Isaac de Moraes. TV Justiça: um instrumento de comunicação pública coordenado pelo Supremo Tribunal Federal. Brasília: Instituto de Educação Superior de Brasília, 2005. SILVA, Virgílio Afonso da; MENDES, Conrado Hübner. Entre a transparência e o populismo judicial. Folha de São Paulo, São Paulo, p. A14, 14 maio 2009. Disponível em: < http:// www1.folha.uol.com.br/fsp/opiniao/fz1105200908.htm >. Acesso em: 10 maio 2017.

SOTELO, José Luiz Vásquez. A jurisprudência vinculante na common law e na civil law. In: CALMON FILHO, Petronio; BELTRAME, Adriana (Org.). Temas atuais de direito processual ibero-americano. Rio de Janeiro: Forense, 1998.

TAVARES, André Ramos. Curso de direito constitucional. 8. ed. São Paulo: Saraiva, 2010. TV JUSTIÇA. Conheça a TV Justiça. Disponível em: <http://www.tvjustica.jus.br/index/ conheca $\geq$ Acesso em: 10 maio 2017a.

. Programas. Disponível em: < http://www.tvjustica.jus.br/index/programa > Acesso em: 10 maio 2017b.

VELlOSO, Carlos Mário da Silva. A TV Justiça deveria parar de transmitir ao vivo as sessões do Supremo Tribunal Federal? Sim. Folha de São Paulo, São Paulo, p. A3, 2 maio 2009. Disponível em: <http://www1.folha.uol.com.br/fsp/opiniao/fz0205200908.htm>. Acesso em: 10 maio 2017.

VIEIRA, Ana Lúcia Menezes. Processo penal e mídia. São Paulo: Revista dos Tribunais, 2003.

VOENA, Giovanni Paolo. Mezzi audiovisivi e pubblicità delle udienze penali. Milano: Giuffrè, 1984.

Submetido: 16 jun. 2017

Aprovado: 18 set. 2017 